\title{
Gender verification of female athletes
}

Louis J. Elsas, $M D^{1}$, Arne Ljungqvist, $M D^{2}$, Malcolm A. Ferguson-Smith, MA, FRCPath ${ }^{3}$, Joe Leigh Simpson, $M D^{4}$, Myron Genel, $M D^{5}$, Alison S. Carlson, BA ${ }^{6}$, Elizabeth Ferris, $M B B S^{7}$, Albert de la Chapelle, $M D, P h D^{8}$, and Anke A. Ehrhardt, $P h D^{9}$

\begin{abstract}
The International Olympic Committee ( $1 O C$ ) officially mandated gender verification for female athletes beginning in 1968 and continuing through 1998. The rationale was to prevent masquerading males and women with "unfair, male-like" physical advantage from competing in female-only events. Visual observation and gynecological examination had been tried on a trial basis for two years at some competitions leading up to the 1968 Olympic Games, but these invasive and demeaning processes were jettisoned in favor of laboratory-based genetic tests. Sex chromatin and more recently DNA analyses for Y-specific male material were then required of all female athletes immediately preceding 10C-sanctioned sporting events, and many other international and national competitions following the IOC model. On-site gender verification has since been found to be highly discriminatory, and the cause of emotional trauma and social stigmatization for many females with problems of intersex who have been screened out from competition. Despite compelling evidence for the lack of scientific merit for chromosome-based screening for gender, as well as its functional and ethical inconsistencies, the $10 \mathrm{C}$ persisted in its policy for 30 years. The coauthors of this manuscript have worked with some success to rescind this policy through educating athletes and sports governors regarding the psychological and physical nature of sexual differentiation, and the inequities of genetic sex testing. In 1990, the International Amateur Athletics Federation (IAAF) called for abandonment of required genetic screening of women athletes, and by 1992 had adopted a fairer, medically justifiable model for preventing only male "impostors" in international track and field. At the recent recommendation of the IOC Athletes Commission, the Executive Board of the $10 \mathrm{C}$ has finally recognized the medical and functional inconsistencies and undue costs of chromosome-based methods. In 1999, the $10 \mathrm{C}$ ratified the abandonment of on-site genetic screening of females at the next Olympic Games in Australia. This article reviews the history and rationales for fairness in female-only sports that have led to the rise and fall of on-site, chromosome-based gender verification at international sporting events. Genetics in Medicine, 2000:2(4):249-254.
\end{abstract}

Key Words: Olympic sports, gender, SRY gene

\section{WOMEN'S PARTICIPATION IN OLYMPIC GAMES}

Olympic Games began in ancient Greece in the $8^{\text {th }}$ century $\mathrm{BC}$ Rules of conduct and criteria for entry were very strict and included being: Trained for at least ten months, of high moral character, not enslaved, and a male. Contests were conducted in the nude and females could not attend, let alone compete. When the modern Olympic movement began in 1896, founder

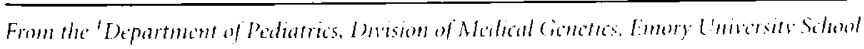

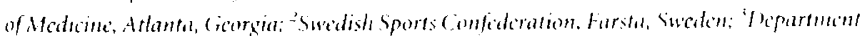

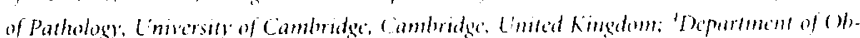

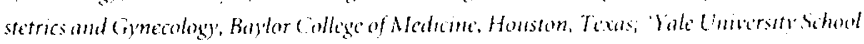

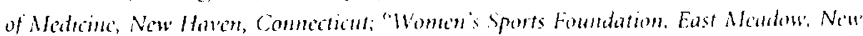

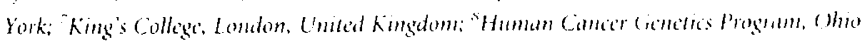

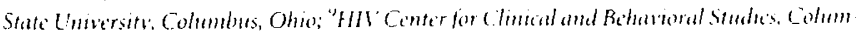
bia Limersity: New lork. New York

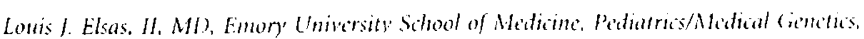
2040 Ritgeweod Drive, Allanta, (GA .3032.2.

Received: March 24, 2000).

Accepted: March 24, 2000 .
Baron Pierre de Coubertin opposed the inclusion of women as competitors, and there was strong cultural resistance to the notion of women as athletes, particularly in events requiring strength and stamina over esthetic qualities. It would be twenty years before women's participation in the Games began in earnest, and it wasn't until after World War II that their numbers became significant. By the 1960s, women's participation surged in world class athletic competition. The number of women-only events increased to include most sports, except equestrian and some yachting events, which remained gender neutral. Nineteen women competed for the first time in the 1900 Olympic Games in Paris. Fifty-seven women competed in Stockholm in 1912, and by 1960, 610 competed in the Rome Olympics. Over the past three decades, 1,000, 1,600, 2,700 and 3,800 women competed in the Summer Olympics of 1972, 1984, 1992 and 1996, respectively. ${ }^{1.2}$ Yet even today, as evidenced by the debate about gender verification, Olympic organizers are still trying to adjust to the inclusion of women as competitors. 


\section{HISTORY OF ON-SITE GENDER VERIFICATION}

As performances were recorded for male and female Olympic events, differentials were documented and segregation by gender continued based on the concept of "fair play." From early on, media reports and rumors fueled concern that men might pose as women in female-only sporting events and that some women competitors might have unfair physical advantage.

The precedent for gender verification was set in 1936 at the Berlin Olympics. German officials felt compelled to issue a statement that the American gold medal sprinter, Helen Stevens, had passed a "sex check" after Polish journalists questioned her femininity. ${ }^{3}$ In 1957, Herman Ratjen confessed that he had been forced under Nazi order to masquerade as a woman named "Dora" in high jump events. He had placed fourth in the 1936 Berlin Olympics, and went on to set a world record in 1938.. Other cases cited as justification for gender verification involved three track and field champions competing as females in the 1930s and ' 40 s who subsequently underwent sex reassignment surgeries. The winner of the 1966 Women's World Cup ski title retired within a year, following a medical exam. After sex reassignment surgery, this skier competed as a man, married and fathered a child. ${ }^{5}$ As a result of these cases, suspicion was focused on a number of dominant, "hyper-masculine" Soviet and Eastern Bloc women athletes in the '50s and ' 60 s. Then in 1980, a coroner's report made public following her accidental shooting death said that the 1932 $100-\mathrm{m}$ sprint champion (and second place finisher to Stevens at the 1936 Olympic women's sprint) had a mosaic sex chromosome pattern and "ambiguity in her sex organs".6

And so the IOC and International Amateur Athletics Federation (IAAF) felt compelled to ensure that "athletes are competing on an equal basis considering their physical status". Both performance-enhancing drugs and sex impostors were to be prevented by on-site testing. The first attempts at gender verification were awkward and demeaning to the contestants. In 1966, women athletes were inspected in the nude by a panel of female physicians at the European Track and Field Championships in Budapest, and in 1967 at the Pan American Games in Winnipeg. Females submitted also to direct gynecological examination at the 1966 Commonwealth Games in Kingston, Jamaica. ${ }^{\circ}$ Complaints arose and the IOC decided to adopt universal, laboratory-based screening for eligibility, namely chromatin testing of buccal cells for the inactive $\mathrm{X}$ (Barr Body). Laboratory testing was called "simpler, objective and more dignified" (Press interview, 1988). ${ }^{7}$ Validation of these tests for their predictive value was not an issue. During a trial run of buccal smear testing in 1967 at the European Cup, Polish sprinter Ewa Klobukowska became the first woman to be disqualified from sports for failing a "sex test" when it was reported she had "an extra chromosome" and "internal, male-like characteristics," and that she had been competing "unwittingly as a man". ${ }^{9}$ Lab-based screens, thus, radically changed the definition of womanhood for sport. Had Klobukowska finished her sports career before the advent of the buccal screen, her sex would never have been questioned. By the early 1970s, geneticists recognized the issues of invalid testing procedures and the harm produced by their use in assigning sex. However, discussions did not alter IOC policy and publications did not appear until the 1980s. ${ }^{10}$

Since then, all female competitors screened out as chromosomally abnormal have either had to withdraw graciously from competition on their own or agree to undergo follow-up gynecological and clinical examination to decide if they should be banned for life, or granted eligibility. According to a 1988 estimate of the IOC's chief of testing, Dr. Eduardo Hay, "one or two women have been banned at each Olympic Games, except for one since 1968" (Personal files of de la Chapelle A. and Carlson A.). Data have been made available only sketchily since then, but it is known that significantly greater numbers of women have chosen to "self-disqualify" out of fear of misunderstanding leading up to competitions or before agreeing to follow-up examination at the Olympics and that many more girls and women have withdrawn or been screened out during qualifying competitions for an Olympic team. ${ }^{10,12}$

It took some time before specific cases and issues became public and illustrated the unreliability and damage caused by chromosome-based screening. Barr body tests had been abandoned during the 1970s, because they were found unreliable. These chromatin tests were screening out women with genetic difference affording no unusual physical advantage for sports (e.g., $\mathrm{XY}$ females with complete androgen insensitivity) while they missed XX men and women with medical conditions such as testosterone-producing ovarian tumors or congenital adrenal hyperplasia. ${ }^{10}$ That the de facto results of genetic screening devastated the lives of screen-positive women was illustrated by the story of Maria Patino, an unsuspecting Spanish national champion hurdle competitor who was screened out at the World University Games and banned from sports in 1985. She had complete androgen insensitivity, and suffered three years of public humiliation and shock. She became the first woman to publicly protest her disqualification and be reinstated. ${ }^{11} \mathrm{Her}$ story and defense ignited what had been a quiescent but growing reform movement to rescind gender verification, not just at IOC games but at all international competitions and at lower levels of sport, where screening was often taking place with no guarantees for quality control. ${ }^{10,12}$

A professional working group of medical specialists, scientists, and athletes began a coordinated discussion of the functional and ethical inconsistencies of on-site chromosomebased gender screening with the objective of affecting IOC policy. After the IAAF convened and sponsored symposia on the subject with this Work Group in Monte Carlo, 1990, and London, 1992, collective conclusions were published to the effect that 1) Individuals with sex-related genetic abnormality raised as females have no unfair physical advantage and should not be excluded or stigmatized. This recommendation included individuals raised as females having non-drug induced masculinization, such as those with 21-steroid-hydroxylase and 5- $\alpha$-steroid-reductase deficiency, incomplete androgen insensitivity and chromosomal mosaicism; 2) Gender screen- 
ing based on finding $\mathrm{Y}$ chromosomal material should be abandoned; and 3) Only masquerading males (individuals reared and living as men) should be excluded. ${ }^{13,14,15}$ Individuals who had undergone prepubertal sex reassignment would be allowed to compete in women-only events. Decisions about postpubertal transsexual cases would be made on an individual basis by the appropriate medical committee within the sport involved.

A critical underpinning to these conclusions is that women with intersex conditions exhibit no differences in biophysical and anatomic scales relevant to sports performance outside the range of possibility for $\mathrm{XX}$ female athletes. Therefore, blanket on-site chromosome screening constitutes invasion of privacy, harassment, and discrimination based on arbitrary assumption of advantage. An ancillary consideration is that well-performed doping controls require direct observation of urine sample collection and should suffice as a deterrent for male masquerading. Either random or "reserve clause" medical evaluation of athletes at international events might be given under limited circumstances. ${ }^{13.15}$

The IAAF reviewed and approved the recommendations of these 1990 and 1992 Symposia and by May of 1992 had formally implemented the model that remains in place today for international women's track and field and professional golf and tennis tours. These policies include eliminating blanket genetic screening with retention of doping control performance as deterrent for male masquerading; and a reserve clause for medical examination by a trained medical delegate, either on a random or individual basis.

In 1993, under advisement from Work Group representatives, both the World University and Commonwealth Games made decisions to suspend blanket chromosome screening at their meets. Of the then 34 international federations with their sport on the Olympic program, only 5 were conducting blanket on-site screening for gender. Events that continued gender verification were weightlifting, shooting, basketball, skiing, and volleyball.

This combination of invalid screening tests; discriminatory singling out of women based only on laboratory results; failure to understand problems of intersex; and stigmatization of positive screened prompted organized objection among medical professionals toward gender verification in sports. By 1996, virtually all major US medical societies had passed resolutions calling for the elimination of gender verification at Olympic Games. These societies included the AMA, AAP, ACP-ASIM, The American College of Obstetrics and Gynecology, The Endocrine Society, Lawson Wilson Pediatric Endocrine Society, and the American Society of Human Genetics. Canadian and Australian genetics societies also passed resolutions opposing blanket gender verification (personal communications with Genel M. and Stevenson J.).

Founders of the IOC's gender verification model, including Prince Alexandre de Mérode (Chairman, IOC Medical Commission) and Dr. Eduardo Hay (Vice Chairman of the IOC Medical Commission and Chief of Gender Verification Testing), remained unchanged in their resolve and interpretation of the parameters of femininity for sport. The IOC remained convinced that genetic-based screening was necessary for protection against male impostors. ${ }^{15,16}$

Some suggested that chromatin screening be replaced by karyotyping of metaphase chromosomes, but this method requires venipuncture and was declined as an alternative. Others suggested blood testing of circulating androgens or just "high stakes" screening of all medalists immediately following competition. However, these suggestions were all fraught with the same functional and ethical pitfalls as the established measures. Ultimately, the IOC decided in 1991 to replace chromatin testing with analysis for $\mathrm{Y}$-specific loci using polymerase chain reaction (PCR) amplification of DNA extracted from nucleated buccal cells. This method enabled rapid screening of everincreasing numbers of female competitors. It was introduced at the Albertville Olympic Winter Games in 1992. At the 1992 Summer Olympics in Barcelona, 2,406 female athletes were screened for both the SRY and DYZ-1 gene loci on the Y chromosome. ${ }^{17}$ Fifteen were found positive, 11 were DYZ-1 positive, and 5 were SRY positive. ${ }^{2}$ No published information is available on the outcome from Barcelona with respect to either the validity of testing or the outcome of positive screened. There was concern among professionals that positive screened were harassed by the press and not allowed to compete even though they were not masquerading males. ${ }^{18,19}$ It was also problematic that the DYZ-1 region of genomic DNA was not male-specific and produced false-positive results.

Critics charged that the IOC had missed the point by adopting yet another genetics based screen. The Norwegian medical community declined to assist the IOC with gender verification in Lillehammer in 1994. The French laboratory from the Albertville games was designated, and no information is available about the results or effects of screening.

Still endorsing the need, the IOC included in its contract with the Atlanta Committee for the Olympic Games a requirement for on-site screening of all female athletes and provision of gender verification cards before allowing females to compete. The Atlanta Committee accepted the IOC requirements and entered into bidding with commercial laboratories for this responsibility. At the 1996 Atlanta Games, a change in testing arrangements was both called for and accomplished. ${ }^{18}$ Coordinated responsibility was given for both the laboratory and clinical evaluation of the screen-positive female to an ABMG certified medical geneticist. This required some confrontational meetings with representatives from the IOC and industry. Agreement was reached that priorities were to prevent masquerading males from competing, to ensure appropriate medical advice, and to do no harm to females with anticipated problems of intersex. A coordinated, confidential laboratory and clinical program was the final consensus to accomplish these aims. Fifty volunteers were recruited for sample collection and laboratory processing; most were females to avoid possible accidental contamination of samples by males. Buccal mucosal cell samples were collected in the confidential setting of a Polyclinic located in the highly secured Olympic Village. If a screen positive sample were found, the athlete was recalled to 
the Polyclinic with her team physician for medical attention and advice. Of the 3,387 athletes who were issued gender verification cards, 296 did not require testing as they had certificates from previous Olympic Games. Approximately $300 \mathrm{fe}-$ male athletes competed in integrated events and did not require gender verification. All samples were analyzed and reported within 48 hours of collection, with an average turnaround time of 22 hours. The presence of the SRY gene was used as a marker of male genetic sex, and an autosomal gene (galactose-1-phosphate uridyltransferase) was used as control to confirm DNA amplification in all samples. Eight of 3,387 female athletes ( 1 in 423 ) tested positive. Seven of the eight had the androgen insensitivity syndrome; four had the incomplete and three the complete syndrome (Table 1). Two of eight had not had gonadectomy. All had full physical examinations and recommendations for follow-up care, including estrogen replacement and appropriate surgical intervention. Letters were written to team physicians explaining the results and, where necessary, recommending further medical evaluation after the Games. One of the eight athletes was found to have 5- $\alpha$-steroid-reductase deficiency. She had had gonadectomy previously, and so there was no question about her eligibility. All eight who tested positive for SRY were given gender verification certificates in the same batch as their teammates to maintain anonymity (Table 1 ).

At the time of testing, all female athletes at the Atlanta Games were offered a questionnaire written in both English and French asking whether in their view testing of females should be continued in future Olympics and whether or not they were made anxious by the testing procedure. ${ }^{18}$ Of the 928 athletes who responded, $82 \%$ felt that testing should be continued and $94 \%$ indicated that they were not made anxious by the procedure. Forty-six athletes were made "anxious" by the testing requirements that preceded their competitive events. No males were found to masquerade as females, and all females who were found to be SRY positive competed. While a similar proportion of females failed the test as in previous Olympics (Table 2), it is noteworthy that on this occasion no false positive tests were found and no athlete was barred from competi-

Table 1

Clinical information on SRY + female athletes at the Centennial Olympics

\begin{tabular}{cccc}
\hline Weight $(\mathrm{kg})$ & Height $(\mathrm{m})$ & Diagnosis $^{a}$ & Gonadectomy \\
\hline 57 & 1.72 & IAIS & NO \\
62 & 1.67 & AIS & NO \\
61 & 1.74 & AIS & YES \\
94 & 1.84 & $5-A-R$ & YES \\
75 & 1.83 & IAIS & YES \\
70 & 1.75 & AIS & YES \\
75 & 1.74 & IAIS & YES \\
68 & 1.71 & IAIS & YES \\
\hline
\end{tabular}

"AIS, Complete androgen insensitivity syndrome; IAIS, incomplete androgen insensitivity syndrome; 5-A-R, 5-alpha-reductase deficiency.
Table 2

Results of genetic testing for gender verification at various Olympic games*

\begin{tabular}{lccc}
\hline Olympic Games & $\begin{array}{c}\text { Number of } \\
\text { Athletes Tested }\end{array}$ & $\begin{array}{c}\text { Number with } \\
\text { Positive Test (\%) }\end{array}$ & Frequency \\
\cline { 2 - 4 } Munich 1972 & 1,280 & $3(0.23)$ & 1 in 426 \\
Montreal 1976 & 1,800 & $4(0.22)$ & 1 in 450 \\
Los Angeles 1984 & 2,500 & $6(0.24)$ & 1 in 416 \\
Barcelona 1992 & 2,406 & $6(0.25)$ & 1 in 401 \\
Atlanta 1996 & 3,387 & $8(0.24)$ & 1 in 423 \\
$\quad$ TOTAL & 11,373 & $27(0.24)$ & 1 in 421 \\
\hline
\end{tabular}

*From Ferguson-Smith' and Elsas et al. ${ }^{18}$

tion. It was interesting in retrospect to consider whether $\mathrm{Y}$ chromosome material increased height in these female athletes. The mean stature of SRY positive athletes was $175 \mathrm{~cm}$ (Table 1). While growth factors on the Y chromosome may increase height, height is not considered an unfair attribute in sporting events. The apparently high frequency of Y chromosome material in elite-class, female athletes is also interesting, but no statistical data are available in a sufficient number of age and ethnically matched, non-athletic females to test relative frequency (Table 2). A rough guess for the frequency of androgen insensitivity syndrome in the female population is $1: 62,000 .^{1}$

Of importance to the IOC in future policy making was the expense and volunteer effort required to accomplish this program. The laboratory testing alone cost over $\$ 150,000$ and this cost did not include the time given voluntarily by 58 professionals who donated from 18 to 90 days of their time. Given the absence of masquerading males; the normal distribution of sports relevant physical differences in XX women athletes; and the cost and complexity of the testing program, there remained a consistent resolve among the professionals involved that screening of female athletes should be abandoned in the future. ${ }^{18}$

\section{SUSPENSION OF LABORATORY-BASED GENDER VERIFICATION SCREENING}

Historically, many women athletes have reflexively supported sex/gender verification policy as a good faith effort to prevent unfair competition. Many initially welcomed it as a reaffirmation of their femininity at a time when cultural biases existed against and certain stigmas were attached to becoming a successful, top-flight woman athlete. ${ }^{20}$ As sociocultural constructs of femininity have changed, so have attitudes toward the need for gender verification. As athletes are educated about the complexities of sex differentiation, the functional and ethical inconsistencies of genetic based screens, and the misconception of unfair advantage underlying the IOC mandate for gender testing, they begin to understand why blanket genetic screening is discriminatory, unnecessary and medically unsound. Because there is consistent anxiety about the potential for cheaters in sports, there are frequent expressions of ner- 
vousness among women athletes about the idea of abandoning per se gender verification. Typically, however, as athletes and sports governors become informed, their reflexive assumptions about the need for blanket screening change. ${ }^{21}$ The chronology of events involved in this change in attitude and the implementation of rescinded activity is outlined in Table 3.

In 1994, the US based Women's Sports Foundation resolved to help educate women athletes about gender verification, issuing a lay review of the debate for athletes and media. ${ }^{20}$ In 1997, the Foundation added a policy statement endorsing the IAAF model. At the IOC World Conference on Women and Sport in Lausanne in April of 1996, a resolution was passed calling for an end to blanket chromosomal screening. ${ }^{22}$ The Norwegian parliament made a decision the same year that genetic testing for the purpose of gender verification in sport would be illegal in Norway. ${ }^{21}$ Modern day sports attire, team training and support systems, and current doping controls make it unlikely that a man could successfully pose as a woman in elite competition today.

The argument for change was considered by the IOC Athletes Commission in 1997-1998 with assistance from Dr. Arne Ljungqvist (IOC Medical Commission member and Chair of the IAAF Medical Committee). Commission member, speedskating gold medalist and medical student, Johann Olav Koss wrote a definitive document on behalf of the Commission rec- ommending the discontinuation of the present system in favor of one relying on IOC Medical Commission intervention on an individualized basis, following scientific and ethical guidelines (personal communications with Professor Arne Ljungqvist).

The IOC Executive Board, at its 1999 session in Seoul, accepted the unanimous recommendation of the Athletes Commission and ratified a resolution that laboratory-based gender screening of all female athletes will not be conducted at the 2000 Millennial Games in Sydney. Prince de Mérode later stated, however, that this decision "is valid only for the Sydney Games" and will be "re-evaluated" at later date. ${ }^{23}$

\section{SUMMARY}

A desire to protect female athletes from unfair competition and to reduce public innuendoes about the sexual identity of trained female athletes resulted in on-site sex verification at the Olympic Games and other competitions beginning in the 1960s. These good intentions resulted at first in demeaning public scrutiny in "nude parades." Attempts at less invasive approaches resulted in scientifically invalid methods using buccal cells for Barr bodies and later PCR-based analyses of $Y$-specific DNA. These approaches stigmatized females with such conditions as androgen insensitivity, XY mosaicism, and

Table 3

Brief history of the rescission of laboratory-based gender verification at Olympic games

\begin{tabular}{|c|c|}
\hline Year & Activity \\
\hline $1968-1988$ & $\begin{array}{l}\text { Informal discussions about pitfalls of gender verification with IOC Medical Commission. Early critics such as Drs. Jean Wilson, Keith Moore, } \\
\text { Marian Krawczynski, Joe Leigh Simpson, and Albert de la Chapelle published objections in medical journals. Prompted by de la Chapelle, } \\
\text { the IOC Medical Commission holds a meeting in } 1988 \text { with critics to review objections but reaffirms their policy and no statement or action } \\
\text { is taken. }\end{array}$ \\
\hline 1988 & $\begin{array}{l}\text { Banned Spanish national champion hurdler Maria Patino appeals her } 1985 \text { disqualification from sports and the IAAF officially reinstates her } \\
\text { eligibility. }\end{array}$ \\
\hline 1990 & $\begin{array}{l}\text { IAAF-sponsored Workshop on Methods of Femininity Verification, Monte Carlo. The Council of the IAAF recommends replacement of } \\
\text { laboratory-based, sex determination with a general health check for all athletes. }\end{array}$ \\
\hline 1991 & $\begin{array}{l}\text { IOC supports need to continue gender verification through an } \mathrm{IOC} \text {-sponsored Medical Commission meeting. Laboratory screening test } \\
\text { changed from examination of buccal cells for Barr Bodies (inactive X chromatin) to DNA-based methods using the polymerase chain } \\
\text { reaction to detect } Y \text { chromosomal material. }\end{array}$ \\
\hline 1992 & $\begin{array}{l}\text { IAAF Workshop on Gender Verification and Symposium for Team Physicians in London confirms previous resolution to discontinue gender } \\
\text { verification at IAAF-recognized competitions, but drops health check recommendation. This resolution holds to date and there have been } \\
\text { neither a requirement for gender verification nor a need to examine a female athlete based on suspicion of imposterism in IAAF } \\
\text { competitions. }\end{array}$ \\
\hline
\end{tabular}

1992 Dr. Arne Ljungqvist becomes a member of the IOC and continues to date an educational program to inform the IOC about scientific and ethical issues related to laboratory-based gender verification.

1996 Most major professional medical societies have passed resolutions against chromosome-based gender screening in sports

1996-1997 IOC World Congress on Woman and Sport passes a resolution to abandon gender verification at the Olympics. Women's Sports Foundation publishes a policy statement against blanket chromosome screening in support of IAAF model. The Norwegian parliament outlaws gender verification in sport. The IOC Medical Commission is unconvinced and the Atlanta Committee for the Olympic Games is contractually committed to on-site, laboratory-based, gender verification of all female athletes competing in women's events.

1997-1998 Arguments for and against change are presented to the IOC Athletes Commission by Professor A. Liungqvist and Dr. B. Dingeon, respectively. Prince de Mérode and Dr. Hay argue for their original policy of blanket gender verification at IOC-sponsored sporting events. Athletes Commission nonetheless calls for the discontinuation of the present system and recommends replacing it with a "reserve clause" system based on IOC Medical Commission intervention on an individualized basis, following scientific and ethical guidelines. 
5 - $\alpha$-reductase-deficiency. Although laboratory-based sex determination caused clear scientific and ethical injustices to female athletes, and the IAAF discontinued the process, the IOC continued to defend their policy. Following the 1996 Centennial Olympic Games in Atlanta, strong voices arose from the IOC World Congress on Women and Sport, the Women's Sports Foundation, and the Athletes Commission of the IOC. These organizations reiterated to the IOC that chromosomalbased gender testing is irrelevant, costly, and highly discriminating; that it has caused unknown numbers of female athletes emotional and social injury; and that on-site blanket gender verification via genetic screening at Olympic Games should be abolished. Its unnecessary cost was stated by those responsible for screening in Atlanta in 1996. In the summer of 1999, the IOC conditionally rescinded its 30 -year requirement for onsite gender screening of all women entered in female-only events at the Olympic Games, starting with Sydney in 2000 . We applaud the IOC's revision and its intent to protect the rights and privacy of female competitors and to maintain its standards of fairness for all athletes. We endorse the continued education of athletes, sports governors, medical delegates, and team physicians concerning the biological complexities of sex differentiation. Since blanket, lab-based screening for gender and fair play is both medically unsound and functionally as well as ethically inconsistent, we hope that the policy stated for the Millennial Games in Sydney will remain.

\section{References}

1. Ferguson-Smith MA. Gender verification and the place of XY females in sport. In: Harries W, Williams C, Stanish W, Micheli L, editors. Oxford textbook of sports medicine, 2nd Ed. Oxford: Oxford University Press, 1998:355-365.
2. Editorial. Women and athletics. The Atlanta Journal and the Atlanta Constitution. Saturday, August 12, 1996:A12-13.

3. Wallechinsky D. The complete book of the Olympics. New York: Penguin, 1988

4. Ryan A. Sex and the singles player. Physicians Sports Med 1976;4:39-41.

5. Ferguson-Smith MA, Ferris EA. Gender verification in sport: the need for change. BrJ Sports Med 1991;25:17-20.

6. Langlais D. "The road not taken: The sex secret that really didn't matter." Running Times, October, 1988;21-22.

7. Hay E. Sex determination in putative female athletes. JAMA 1972;4:39-41.

8. Ferris E.A. Gender verification testing in sport. Br Med Bull 1992;48:1-15.

9. Larned D. The femininity test: "Woman's first hurdle." Woman Sport, July 1976:911,41

10. de la Chapelle $A$. The use and misuse of sex chromatin screening for "gender verification" of female athletes. JAMA 1986;256:1920-1923.

11. Carlson A. "When is a woman not a woman?" Women's Sport of Fitness. March 1991:24-29.

12. Simpson JL. Gender testing in the Olympics. JAMA 1986;256:1938.

13. Simpson JL, Ljungqvist A, de la Chapelle A, Ferguson-Smith MA, Gene] M, Carlson A, Ehrhardt A, Ferris E. Gender verification in competitive sports. Sports Med 1993 16:305-315.

14. Ljungqvist A, Simpson J. Medical examination for health of all athletes replacing the need for gender verification in international sport. JAMA 1992;277:850-852.

15. International Amateur Athletic Federation/International Athletic Federation. Reports on approved methods of femininity verification. Monte Carlo: IAFF/IAF, November, 1990.

16. Dingeon $B$, Harmon $P$, Robert $M$, Schamasch $P$, Pugeat $M$. Sex testing at the Olympics. Nature 1992;358:447.

17. Serrat A, Garcia de Herreros A. Determination of genetic sex by PCR amplification of Y-chromosome-specific sequences. Lancet 1993;341:1593-1594.

18. Elsas LJ, Hayes RP, Muralidharan K. Gender verification at the Centennial Olympic Games. J Med Assoc Ga 1997;86:50-54.

19. Letter from Ferguson-Smith M to Garcia de Herreros A. May 11, 1993.

20. Carlson A. Sex/gender verification in international sports: the need to re-examine policy and our notions of femininity, physical equality and fair play. Women's Sports Foundation Lay Review Paper, 1994.

21. Ljungqvist A. Women in sport. In: Drinkwater BL, editor. Olympic encyclopedia, vol III. Oxford: Blackwell Science, Ltd., 2000:183-193.

22. Stephenson J. Female Olympians' sex tests outmoded. JAMA 1996;276:177-178.

23. International Olympic Committee. Minutes of $109^{\text {th }}$ IOC Session; 1999 June 17-20; Seoul, Korea. 